\title{
Flexural Behavior of Partially Replaced Prosopis Juliflora Concrete
}

\author{
S.Vinothkumar, S. Rajesh, Anish .C
}

\begin{abstract}
The test examinations are done to consider the impact of prosopis juliflora in RCC structure by halfway substitution or including bond. Prosopis juliflora inflorescence is about nothing, green-yellowish spikes with no specific smell or interfacing with quality, at any rate refreshing by honey bees. Prosopis juliflora is one of these animal packs that has performed much superior to different neighborhood woody species. As of now, prosopis juliflora gives around $75 \%$ of fuel wood needs of country individuals in dry and semi dried areas of India. An exploratory examination is done on a solid containing waste prosopis juliflora scorching trash in the varying extent weight for bond. Material was passed on, endeavored and separated and standard security like value and quality. These tests were done on standard light transmission mm for 28 days to pick the mechanical properties of cement.
\end{abstract}

Keywords : sub- Prosopis juliflora, fuel wood, conventional, attractiveness, concrete.

\section{INTRODUCTION}

P.juliflora leaves have been utilized as continuing cattles and people. Inebriation with plant has been spoken to and is depicted [2 ],[4],[6] by neuromuscular changes and gliosis. Plant improvement and profitability are unjustifiably affected by different abiotic stress factors. Prosopis juliflora is a solid plant offered a clarification to be tolerant to dry spell, saltiness, breaking points of soil $\mathrm{pH}$, and noteworthy metal weight. All pieces of P.juliflora is bounteously being utilized in different fields. Research in making P. juliflora for its alleopathy, medicinal and bio-pesticide will altogether impact movement of new solutions and pesticides.

\section{TEST BLOCK PREPARATION}

Before beginning setting time test, do the consistency test to get the water required to give the glue ordinary consistency (P) [25],[27],[29]. Take $400 \mathrm{~g}$ of bond and set up a perfect strong glue with $0.85 \mathrm{P}$ of water by weight of concrete. Check time is kept between 3 to 5 minutes. Begin the stop watch right when the water is added to the strong

\section{A. Sieve Analysis}

Play out the hand procedure for sieving by techniques for a flat and vertical development of the sifter, joined by a knocking movement, so as to keep the model moving determinedly over the outside of the strainer[26],[28],[30]. Do whatever it takes not to turn or control particles through the strainer by hand. Continue sieving until not more than $0.5 \%$ by mass of the total model will pass any strainer during one additional snapshot of hand sieving. Record this time (t1).

Fill the Vicat shape, laying on a glass plate, with the strong glue checked as above. Fill the shape completely and smooth off the outside of the glue making it level with the most significant reason for the structure. The strong square thusly composed is called test square[31],[33]

\section{RESULT AND DISCUSSION}

Table 1 - Properties of materials

\begin{tabular}{|l|c|r|}
\hline \multirow{2}{*}{ PROPERTY } & \multicolumn{2}{|c|}{ RESULT } \\
\hline $\begin{array}{l}\text { BULK DENSITY } \\
\begin{array}{c}\text { FOR FINE } \\
\text { AGGREGATE }\end{array}\end{array}$ & LOOSE & $1.54 \mathrm{Kg} / 1$ \\
\cline { 2 - 3 } & RODDED & $1.67 \mathrm{Kg} / 1$ \\
\hline $\begin{array}{l}\text { BULK DENSITY } \\
\text { FOR COARSE } \\
\text { AGGREGATE }\end{array}$ & LOOSE & $1.53 \mathrm{Kg} / 1$ \\
\cline { 2 - 3 } & RODDED & $1.68 \mathrm{Kg} / 1$ \\
\hline
\end{tabular}

Figure - 1 Compressive strength in 14 days

Revised Manuscript Received on July 22, 2019.

S.Vinothkumar , Assistant Professor, Department of Civil Engineering, Bharath Institute of Higher Education and Research, Chennai, India. Email: vinothsenna@gmail.com

S. Rajesh, Assistant Professor, Department of Civil Engineering, Bharath Institute of Higher Education and Research, Chennai, India. Email: rajeshskr06@gmail.com

Anish .C, Assistant Professor, Department of Civil Engineering, Bharath Institute of Higher Education and Research, Chennai, India. Email: anishdavidpaul@gmail.com 


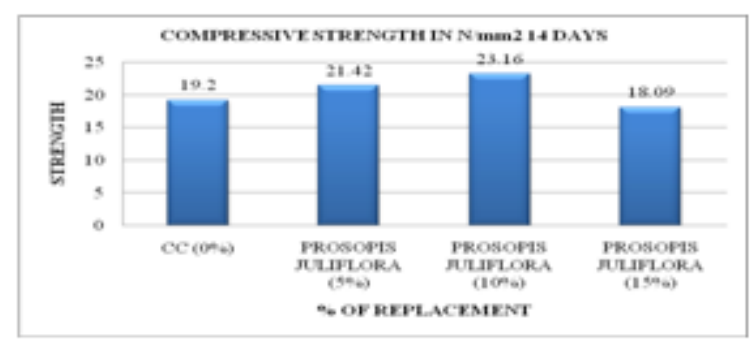

\begin{tabular}{|c|r|c|c|c|}
\hline \multirow{3}{*}{$\begin{array}{l}\text { CONTROL } \\
\text { MIX }\end{array}$} & \multicolumn{4}{|c|}{ COMPRESSIVE STRENGTH IN N/mm ${ }^{2}$} \\
\cline { 2 - 5 } & CC & PROSO & PROS & PROS \\
& $(0 \%)$ & PIS & OPIS & OPIS \\
& & JULIFLO & JULIFL & JULIFL \\
& & RA (5\%) & ORA & ORA \\
& & & $(10 \%)$ & $(15 \%)$ \\
\hline M20 & 22.71 & 25.6 & 30.58 & 21.02 \\
\hline
\end{tabular}

Table 2- Compressive strength in 28 days

\begin{tabular}{|c|c|c|c|c|}
\hline \multirow{3}{*}{$\begin{array}{c}\text { CONTROL } \\
\text { MIX }\end{array}$} & \multicolumn{4}{|c|}{ COMPRESSIVE STRENGTH IN N/mm } \\
& \multicolumn{4}{|c|}{28 DAYS } \\
\cline { 2 - 5 } & CC & PROSO & PROS & PROS \\
& $(0 \%)$ & PIS & OPIS & OPIS \\
& & JULIFLO & JULIFL & JULIFL \\
& & RA (5\%) & ORA & ORA \\
& & & $(10 \%)$ & $(15 \%)$ \\
\hline M20 & 22.71 & 25.6 & 30.58 & 21.02 \\
\hline
\end{tabular}

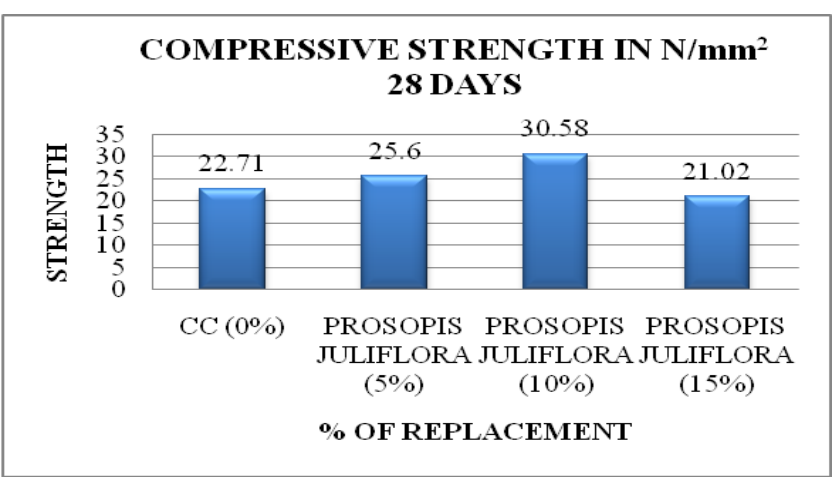

Table 3- Split tensile strength test

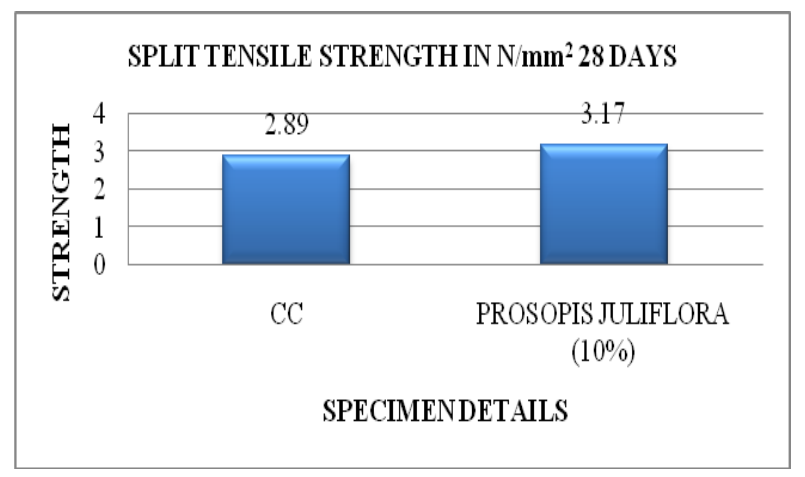

\section{REFERENCES}

1. Iyappan L., Dayakar P., Identification of landslide prone zone for coonoortalukusing spatial technology, International Journal of Applied Engineering Research,V-9,I-22,PP-5724-5732,Y-2014.

2. Kumar J., Sathish Kumar K., Dayakar P.,Effect of microsilica on high strength concrete, International Journal of Applied Engineering Research,V-9,I-22,PP-5427-5432,Y-2014.

3. Dayakar P., Vijay Ruthrapathi G., Prakesh J., Management of bio-medical waste, International Journal of Applied Engineering Research,V-9,I-22,PP-5518-5526,Y-2014.

4. Swaminathan N., Dayakar P., Resource optimization in construction project, 
International Journal of Applied Engineering Research,V-9,I-22,PP-5546-5551,Y-2014.

5. Venkat Raman K., Dayakar P., Raju K.V.B.,An experimental study on effect of cone diameters in penetration test on sandy soil, International Journal of Civil Engineering and Technology,V-8,I-8,PP-1581-1588,Y-2017.

6. Saritha B., Chockalingam M.P.,Photodradation of malachite green DYE using TIO2/activated carbon composite, International Journal of Civil Engineering and Technology,V-8,I-8,PP-156-163,Y-2017

7. Shendge R.B., Chockalingam M.P., Saritha B., Ambica A.,Swat modelling for sediment yield: A case study of Ujjani reservoir in Maharashtra, India,International Journal of Civil Engineering and Technology,V-9,I-1,PP-245-252,Y-2018

8. Chockalingam M.P., Balamurgan V.,Modernisation of an existing urban road-sector in Chennai, a case study report,International Journal of Civil Engineering and Technology,V-8,I-8,PP-1457-1467,Y-2017

9. Saritha B., Chockalingam M.P.,Adsorption study on removal of basic dye by modified coconut shell adsorbent, International Journal of Civil Engineering and Technology,V-8,I-8,PP-1370-1374,Y-2017

10. Saritha B., Chockalingam M.P.,Adsorptive removal of heavy metal chromium from aqueous medium using modified natural adsorbent,International Journal of Civil Engineering and Technology,V-8,I-8,PP-1382-1387,Y-2017

11. Chockalingam M.P., Palanivelraja S.,Retrospective analysis of a theoretical model used for forecasting future air quality near the north Chennai thermal power plant,International Journal of Civil Engineering and Technology,V-8,I-8,PP-1457-1467,Y-2017

12. Saritha B., Chockalingam M.P.,Photodegradation of methylene blue dye in aqueous medium by $\mathrm{Fe}-\mathrm{AC} / \mathrm{TiO} 2$ Composite,Nature Environment and Pollution Technology,V-17,I-4,PP-1259-1265,Y-2018

13. Shendge R.B., Chockalingam M.P., Kaviya B., Ambica A.,Estimates of potential evapotranspiration rates by three methods in upper Bhima Basin, In Maharashtra, India,International Journal of Civil Engineering and Technology,V-9,I-2,PP-475-480,Y-2018

14. Shendge R.B., Chockalingam M.P.,The soil and water assessment tool for Ujjani Reservoir,International Journal of Mechanical Engineering and Technology,V-9,I-2,PP-354-359,Y-2018

15. Shendge R.B., Chockalingam M.P.,A review on soil and wate assessment tool,International Journal of Mechanical Engineering and Technology,V-9,I-2,PP-347-353,Y-2018

16. Sachithanandam P., Meikandaan T.P., Srividya T.,Steel framed multi storey residential building analysis and design,International Journal of Applied Engineering Research,V-9,I-22,PP-5527-5529,Y-2014

17. Meikandaan T.P., Ramachandra Murthy A.,Study of damaged RC beams repaired by bonding of CFRP laminates,International Journa of Civil Engineering and Technology,V-8,I-2,PP-470-486,Y-2017

18. Meikandaan T.P., Ramachandra Murthy A.,Retrofittng of reinforced concrete beams using GFRP overlays,International Journal of Civil Engineering and Technology,V-8,I-2,PP-423-439,Y-2017

19. Meikandaan T.P., Ramachandra Murthy A.,Flexural behaviour of RC beam wrapped with GFRP sheets,International Journal of Civil Engineering and Technology,V-8,I-2,PP-452-469,Y-2017

20. Meikandaan T.P., Murthy A.R.,Experimental study on strengthening of rc beams using glass Fiber,International Journal of Civi Engineering and Technology,V-9,I-11,PP-959-965,Y-2018

21. Meikandaan T.P., Hemapriya M.,Use of glass FRP sheets as externa flexural reinforcement in RCC Beam,International Journal of Civil Engineering and Technology,V-8,I-8,PP-1485-1501,Y-2017

22. Saraswathy R., Saritha B.,Planning of integrated satellite township at Thirumazhisai,International Journal of Applied Engineering Research,V-9,I-22,PP-5558-5560,Y-2014

23. Saritha B., Ilayaraja K., Eqyaabal Z.,Geo textiles and geo synthetics for soil reinforcement,International Journal of Applied Engineering Research,V-9,I-22,PP-5533-5536,Y-2014

24. Ambica A., Saritha B., Changring G., Singh N B., Rajen M., Salman Md.,Analysis of groundwater quality in and around Tambaram taluk, Kancheepuram district,International Journal of Civil Engineering and Technology,V-8,I-8,PP-1362-1369,Y-2017

25. Arunya A., Sarayu K., Ramachandra Murthy A., Iyer N.R.,Enhancement of durability properties of bioconcrete incorporated with nano silica,International Journal of Civil Engineering and Technology,V-8,I-8,PP-1388-1394,Y-2017

26. Ilayaraja K., Krishnamurthy R.R., Jayaprakash M., Velmurugan P.M., Muthuraj S.,Characterization of the 26 December 2004 tsunam deposits in Andaman Islands (Bay of Bengal, India),Environmental Earth Sciences,V-66,I-8,PP-2459-2476,Y-2012

27. Ilayaraja K.,Morphometric parameters of micro watershed in Paravanar sub-basin, Cuddalore District,International Journal of Civil Engineering and Technology,V-8,I-8,PP-1444-1449,Y-2017
28. Ilayaraja K., Singh R.K., Rana N., Chauhan R., Sutradhar N.,Site suitability assessment for residential areas in south Chennai region using remote sensing and GIS techniques,International Journal of Civil Engineering and Technology,V-8,I-8,PP-1468-1475,Y-2017

29. Ilayaraja K., Reza W., Kumar V., Paul S., Chowdhary R.,Estimation of land surface temperature of Chennai metropolitan area using Landsat images,International Journal of Civil Engineering and Technology,V-8,I-8,PP-1450-1456,Y-2017

30. Chitra R.,Experimental study on beam using steel fiber and latex,International Journal of Civil Engineering and Technology,V-8,I-8,PP-1395-1403,Y-2017

31. Chitra R.,Analysis of traffic and management at Kovilambakkam intersection,International Journal of Civil Engineering and Technology,V-8,I-8,PP-1433-1443,Y-2017

32. Aswathy M.,Experimental study on light weight foamed concrete,International Journal of Civil Engineering and Technology,V-8,I-8,PP-1404-1412,Y-2017

33. Aswathy M.,Wastewater treatment using constructed wetland with water lettuce (Eichornia Crasipies),International Journal of Civil Engineering and Technology,V-8,I-8,PP-1413-1421,Y-2017

34. Kiruthiga K., Anandh K.S., Gunasekaran K, Assessment of influencing factors on improving effectiveness and productivity of construction engineers, 2015, International Journal of Applied Engineering Research, V - 10,I -17,p -13849-13854.

\section{AUTHORS PROFILE}

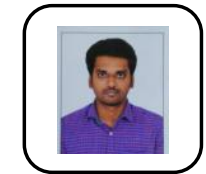

S.Vinothkumar, Assistant Professor, Department of Civil Engineering, Bharath Institute of Higher Education and Research, Chennai, India

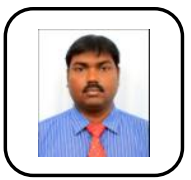

S. Rajesh, Assistant Professor, Department of Civil Engineering, Bharath Institute of Higher Education and Research, Chennai, India

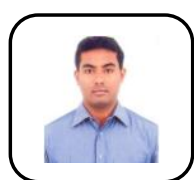

Anish .C, Assistant Professor, Department of Civil Engineering, Bharath Institute of Higher Education and Research, Chennai, India 